\title{
Effect of Xylazine-Ketamine Anesthesia on Blood ACTH, Cortisol, Adrenaline, Insulin and Glucose in Ovariohysterectomized Cats
}

\author{
Nadya Zlatozareva Zlateva-Panayotova and Bogdan Yanev Aminkov \\ Department of Surgery, Anesthesiology and Radiology, Faculty of Veterinary Medicine University of Forestry, Sofia 1505, Bulgaria
}

Received: May 3, 2015 / Accepted: May 6, 2015 / Published: May 30, 2015.

\begin{abstract}
A study has been carried out with fourteen healthy mature cats in order to determine the effect of a xylazine-ketamine anesthetic protocol (group X/K) on blood concentrations of adrenaline, ACTH (adrenocorticotropic hormone), cortisol, insulin and glucose in comparison with a control group (group $\mathrm{K}-$ no anesthesia and surgery). The animals were randomly allocated in two groups $(\mathrm{n}=7)$. The premedication in the experimental group was made with xylazine $2 \mathrm{mg} / \mathrm{kg}$ intramuscularly. Induction and maintenance of anesthesia were made with ketamine $10 \mathrm{mg} / \mathrm{kg}$ intramuscularly. Ovariohysterectomy was performed upon occurrence of deep anesthesia. Blood specimens were obtained at 0,30,60, $120 \mathrm{~min}$ and $24 \mathrm{~h}$ from the two groups. Pronounced decrease in blood ACTH, cortisol, and adrenaline in group $\mathrm{X} / \mathrm{K}$ was determined by the $30 \mathrm{~min}$. Significant hyperglycemia together with hyperinsulinemia in the $\mathrm{X} / \mathrm{K}$ group was established at the $120 \mathrm{~min}$ from the beginning of the anesthesia. Anesthesia with xylazine and ketamine led to reduction of the blood levels of stress hormones immediately after the beginning of anesthesia and caused a remarkable hyperglycemia with hyperinsulinemia.
\end{abstract}

Key words: Anesthesia, cats, adrenaline, cortisol, ACTH, insulin.

\section{Introduction}

A number of previous studies have found that the endocrine response depended on anesthesia, the combinations of various anesthetic agents, surgical procedures, level of pain, etc. The endocrine changes during and after anesthesia were studied in different animal species, but the investigations in cats are limited [1-3].

The combination of xylazine and ketamine is often used in veterinary practice for different operations with short duration. This anesthetic protocol is easy to apply and relatively inexpensive. The side effects of $\alpha_{2}$-adrenoreceptors are usually associated with the cardiovascular system [4], but their neuroendocrine effects in cats are not fully understood. The

Corresponding author: Nadya Zlatozareva Zlateva-Panayotova, Ph.D., research fields: anesthesiology and small animals. E-mail: dr.zlateva71@gmail.com. $\alpha_{2}$-agonists strongly interfere with the neuroendocrine system and could be a predisposing cause for different diseases such as diabetes mellitus, Cushing disease, etc. [2].

The dissociative anesthetics have also endocrine effects. They act on receptor systems involved in the physiological stress response [5]. There is therefore a certain analogy between the endocrine effects of analgesics and the stress response.

The combination of $\alpha_{2}$-adrenoreceptor agonists and dissociative anesthetic agents provides a better analgesic effect, but could also cause changes in stress-related hormones, such as ACTH, cortisol, adrenaline and insulin $[1,4,6]$. The information for the neurohormonal effects of this anesthetic protocol in cats is limited [3].

The aim of the study was to investigate the effects of xylazin-ketamine anesthesia on plasma concentrations of ACTH, cortisol, adrenaline, insulin 
and serum blood glucose during ovariohysterectomy in cats in comparison with a control group not submitted to anesthesia and surgery.

\section{Materials and Methods}

\subsection{Animals}

Fourteen female cats at the age between 2 and 4 years, weighing 2.8-3.9 kg, mixed breed, were included in the study. Two weeks before the experiment, the animals were kept in the University Clinic for Small Animals at the Faculty of Veterinary Medicine, University of Forestry, Sofia. They were fed commercial dry food without limitation except for the $12 \mathrm{~h}$ fasting period before the anesthesia and surgery. The water was restricted two hours before surgery. Immediately prior to the experiment, the animals were examined and determined to be clinically healthy on the basis of the physical and blood laboratory examinations, including complete blood counts and total protein. All values were within normal physiological ranges.

The cats were randomly allocated in two groups - control $(\mathrm{K})$ and experimental $(\mathrm{X} / \mathrm{K})$ group $(\mathrm{n}=7$ in each group). The premedication in the experimental group was made with xylazine hydrochloride $2 \mathrm{mg} / \mathrm{kg}$ (Xylasin ${ }^{\circledR}$, Alfazan-Turkey) intramuscularly. All animals were submitted to fluid therapy with sodium chloride $0.9 \%, 10 \mathrm{~mL} / \mathrm{kg} / \mathrm{h}$

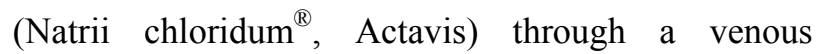
catheter 22 gauge (B. Braun) applied in v. cephalica antebrachii. Induction of anesthesia was made with ketamine hydrochloride, (Ketamin, Intervet-Holand) $10 \mathrm{mg} / \mathrm{kg}$ body weight intravenously, five minutes after the premedication. Immediately after the application of the general anesthesia, the animals were intubated with a tube of a suitable size. The oxygen flow was $2.5 \mathrm{~L} / \mathrm{min}$ by using semi-opened breathing circuit system type T/Y detail, Kuhn modification. The extubation was made after manifestation of swallowing reflex. The anesthetics were not given to the animals from control group.

\subsection{Surgery Protocol}

Ovariohysterectomy was performed through caudal median laparotomy. The average duration of the operation was between 8 and 10 min. Surgery started $30 \mathrm{~min}$ after the initiation of anesthesia at the surgical plane of anesthesia.

\subsection{Collection of Blood Specimens}

Blood specimens were obtained from the jugular vein in sterile $2.0 \mathrm{~mL}$ syringes by $23 \mathrm{G}$ needles at strictly determined intervals - at $0 \mathrm{~min}$ (before the application of the anesthetics) 30, 60, $120 \mathrm{~min}$ and 24 $\mathrm{h}$ from the beginning of the anesthesia. Immediately after collection of the specimens, $1.5 \mathrm{~mL}$ of each sample was put into a sterile micro vacutainer, containing heparin and centrifuged for $15 \mathrm{~min}$ at room temperature for hormonal analysis. The plasma specimens were stored at $22{ }^{\circ} \mathrm{C}$ for 27 days, prior to determination of the hormone concentrations.

The rest $0.5 \mathrm{~mL}$ aliquot was put in sterile micro vacutainers without anticoagulant for blood glucose analysis. The specimens were incubated for two hours at $37{ }^{\circ} \mathrm{C}$ to form a clot and after centrifugation the obtained serum was immediately analyzed to determine the blood glucose concentrations.

\subsection{Analytical Methods of Study}

Cortisol—by ADVIA Centaur ${ }^{\circledR}$ Cortisol test, Bayer Diagnostics. The examination was made by IMMULITE $^{\circledR} \quad 2000 / 2500$ apparatus, Siemens, Germany. Enzyme Conjugate-Cortisol conjugated to horseradish peroxidase. The inter-assay $\mathrm{CVs}$ ranged between $6.5 \%$ and $7.7 \%$. The limit of quantification was $6.9 \mathrm{nmol} / \mathrm{L}$; Insulin - by specific Insulin ELISA test, Mercodia, Sweden. The test used feline insulin as calibration solution. The limit of quantification was $9.2 \mathrm{ng} / \mathrm{L}$. The inter-assay CVs ranged between $6.7 \%$ and $12.5 \%$; Adrenaline - by specific enzyme test Adrenaline-ELISA DRG Adrenaline ELISA, EIA_4306-for quantitative determination of adrenaline in animal plasma, DRG Instruments $\mathrm{GmbH}$, 
Germany. Enzyme Conjugate-anti-rabbit IgG conjugated with peroxidise. The limit of quantification for plasma was $60 \mathrm{pmol} / \mathrm{L}$. The inter-assay $\mathrm{CVs}$ ranged between $13.2 \%$ and $15.4 \%$; Adrenocorticotropic hormone-by specific enzyme test ACTH ELISA-test, 21-ACTHU-E01, ALPCO Diagnostics, USA, using lyophilized feline ACTH as a calibration solution. The limit of quantification was $0.1 \mathrm{pmol} / \mathrm{L}$. The inter-assay $\mathrm{CVs}$ ranged between $5.8 \%$ and $6.2 \%$. The hormonal assays of adrenaline, ACTH and insulin were carried out by ELISA Reader Microplate Reader, France.

Blood glucose was quantitated by oxidase enzyme test (Spinreact, Glucose TR, Spain) on Biochemical Analysis System Hitachi 7,070, Japan. The inter-assay CVs ranged between $1.58 \%$ and $1.50 \%$. The limit of quantification was $0.05 \mathrm{mmol} / \mathrm{L}$.

\subsection{Statistical Analysis}

All data were expressed as mean and standard deviation (mean $\pm \mathrm{SD}$ ). Differences between the two groups were analyzed using one way ANOVA (analysis of variance) and the least-significant difference (LSD) post hoc test at a level of significance 0.05 .

The study was approved by the Committee on Animal Ethics at the National Veterinary Service in Bulgaria.

\section{Results}

When comparing the obtained values of the examined analytes, no significant differences in the initial concentrations $(0 \mathrm{~min})$ between the two groups were determined.

A significant hyperglycemia was observed in group $\mathrm{X} / \mathrm{K}$ at the $30 \min (9.3 \pm 3.1 \mathrm{mmol} / \mathrm{L}), 60 \min (15.3 \pm$ $2.4 \mathrm{mmol} / \mathrm{L})$ and $120 \mathrm{~min}-18.1 \pm 1.3 \mathrm{mmol} / \mathrm{L}(p<$ $0.001)$ together with increased insulin concentrations at the same periods $-30 \mathrm{~min}-49.2 \pm 11.5 \mathrm{pmol} / \mathrm{L}(p<$ $0.01), \quad 60 \mathrm{~min}-68.0 \pm 23.4 \mathrm{pmol} / \mathrm{L}$ and 120 $\min -93.3 \pm 23.9 \mathrm{pmol} / \mathrm{L}(P<0.001)$.
The cortisol concentrations were decreased at the $30 \mathrm{~min}-154.5 \pm 19.5 \mathrm{nmol} / \mathrm{L}(P<0.001)$ and its values were unchanged by the $60 \mathrm{~min}$ and $120 \mathrm{~min}$. By the $24 \mathrm{~h}$ the concentration of cortisol was similar to the baseline values. The lowest adrenaline concentrations were determined at the $60 \mathrm{~min}-89.5 \pm$ $2.0 \mathrm{pmol} / \mathrm{L}$ as compared to the initial values.

A significant decrease of the ACTH concentration in group $\mathrm{X} / \mathrm{K}$, compared to the initial values, was determined at the $30 \mathrm{~min}-0.9 \pm 0.6 \mathrm{pmol} / \mathrm{L}(P<$ 0.01 ). By the $60 \mathrm{~min}$ and $120 \mathrm{~min}$ the concentrations of ACTH in this group were significant lower $-0.4 \pm$ $0.2(P<0.001)$ and $0.2 \pm 0.04(P<0.001)$. By the 24 $\mathrm{h}$ the concentration of ACTH was similar to the baseline values (Table 1).

The blood glucose and insulin concentrations in control group were unchanged. A significant increase of the cortisol concentration in group $\mathrm{K}$, compared to the initial values, was determined at the $24 \mathrm{~h}-338.4 \pm$ $4.3 \mathrm{nmol} / \mathrm{L}(P<0.01)$. The adrenaline concentrations were increased significantly at the $30 \mathrm{~min}-103.8 \pm$ $1.5 \mathrm{pmol} / \mathrm{L}(P<0.01)$, but at the $60 \mathrm{~min}$ and $120 \mathrm{~min}$ they were similar to the baseline values. Unlike that, by the $24 \mathrm{~h}$, adrenaline concentrations of group $\mathrm{K}$ were higher that initial values $-121.3 \pm 1.0 \mathrm{pmol} / \mathrm{L}$ $(P<0.01)$.

Significant increase of $\mathrm{ACTH}$ concentration in group $\mathrm{K}$ was determined by the $30 \mathrm{~min}-2.2 \pm 0.2$ $\mathrm{pmol} / \mathrm{L}(P<0.05)$ and $24 \mathrm{~h}-2.4 \pm 0.1 \mathrm{pmol} / \mathrm{L}$ $(P<0.001)$, however by the $60 \mathrm{~min}$ the concentrations were statistically significantly lower-1.67 \pm 0.2 $\mathrm{pmol} / \mathrm{L}(P<0.01)$, in comparison with initial ones.

The analysis of blood glucose concentrations of both groups demonstrated statistically significantly higher values in group $\mathrm{X} / \mathrm{K}$ by the $30 \mathrm{~min}(9.3 \pm$ $3.1 \mathrm{mmol} / \mathrm{L}), 60 \mathrm{~min}(15.3 \pm 2.4 \mathrm{mmol} / \mathrm{L})$ and 120 $\min (18.1 \pm 1.3 \mathrm{mmol} / \mathrm{L}), P<0.001$ as compared to group $\mathrm{K}$.

Blood plasma insulin differed significantly between the groups on all periods of examination.

Cortisol concentrations in group $\mathrm{X} / \mathrm{K}$ were 
statistically significantly lower by $\min 30: 154.5 \pm$ $19.5 \mathrm{nmol} / \mathrm{L}(P<0.05)$, $\min 60: 159.0 \pm 5.4 \mathrm{nmol} / \mathrm{L}$ $(P<0.001)$ and hour 24: $233.0 \pm 43.8(P<0.01)$ compared to group $\mathrm{K}$. A significantly lower adrenaline concentration in group $\mathrm{X} / \mathrm{K}$ vs. group $\mathrm{K}$ was established at $30 \mathrm{~min}-92.0 \pm 0.7 \mathrm{pmol} / \mathrm{L}(P<0.05)$ and $24 \mathrm{~h}$ after the anesthesia $-95.9 \pm 6.1(P<0.001)$. Blood plasma ACTH of group $\mathrm{X} / \mathrm{K}$ turned out to be considerably decreased $(P<0.001)$ compared to group $\mathrm{K}$ by the $30 \mathrm{~min}, 60 \mathrm{~min}$ and $120 \mathrm{~min}$. By the $24 \mathrm{~h}, \mathrm{ACTH}$ concentrations of the group anesthetized with xylazine and ketamine-1.8 $\pm 0.4 \mathrm{pmol} / \mathrm{L}$ - were lower $(P<0.01)$ than respective values of group $\mathrm{K}-2.4 \pm 0.1(1.8-2.5) \mathrm{pmol} / \mathrm{L}$ (Table 1$)$.

\section{Discussion}

Alpha $_{2}$-agonists are known to inhibit the sympathetic nervous system via their influence on $\alpha_{2}$-adrenoreceptors causing decrease in circulating catecholamine concentrations $[7,8]$, either with or without surgery [9] including in cats [2, 3]. On the other hand, being a NMDA antagonist, ketamine could stimulate or inhibit sympathetic activity $[10,11]$.
The authors have shown that the xylazine/ketamine combination resulted in an insignificant reduction of blood adrenaline immediately after anesthetic drug application which persisted until the end of the experiment.

$\mathrm{Alpha}_{2}$-adrenoreceptor agonists inhibit cortisol secretion, but it is still disputable whether these effects are mediated only via $\alpha_{2}$-receptors or other receptors are also involved. Recent reports suggest that imidazoline receptors play probably a role in the inhibition of cortisol secretion [2]. An in vitro study demonstrates that imidazoline $\alpha_{2}$ - adrenergic agents medetomidine, detomidine and atipamezole inhibit cortisol secretion in porcine adrenocortical cells [12]. As medetomidine and detomidine are selective $\alpha_{2}$-adrenoceptor agonists, and atipamezole-a selective $\alpha_{2}$-adrenoreceptor antagonist, their effects could not be mediated via influence on $\alpha_{2}$-adrenoreceptors only [8, 13]. Therefore, the secretion of ACTH and cortisol is probably mediated through imidazoline receptors as well.

In rats, xylazine and ketamine co-administration results in reduction of blood $\mathrm{ACTH}$ and corticosterone

Table 1 Changes in the concentrations of blood glucose, insulin, cortisol, adrenaline and ACTH in group X/K and group K.

\begin{tabular}{|c|c|c|c|c|c|}
\hline & $0 \mathrm{~min}$ & $30 \mathrm{~min}$ & $60 \mathrm{~min}$ & $120 \mathrm{~min}$ & $24 \mathrm{~h}$ \\
\hline $\begin{array}{l}\text { Glucose } \\
(\mathrm{mmol} / \mathrm{L}) \\
\text { Group X/K }\end{array}$ & $5.2 \pm 0.7$ & $\begin{array}{l}9.3 \pm 3.1 \\
* * * \# \# \#\end{array}$ & $\begin{array}{l}15.3 \pm 2.4 \\
* * * \# \# \#\end{array}$ & $\begin{array}{l}18.1 \pm 1.3 \\
* * * \# \# \#\end{array}$ & $4.2 \pm 1.6$ \\
\hline Group K & $4.4 \pm 0.9$ & $4.5 \pm 0.9$ & $4.4 \pm 1.2$ & $5.0 \pm 0.9$ & $5.1 \pm 0.9$ \\
\hline $\begin{array}{l}\text { Insulin }(\mathrm{pmol} / \mathrm{L}) \\
\text { Group X/K }\end{array}$ & $19.4 \pm 5.6$ & $\begin{array}{l}49.2 \pm 11.5 \\
* * \# \# \#\end{array}$ & $\begin{array}{l}68.0 \pm 23.4 \\
* * * \# \# \#\end{array}$ & $\begin{array}{l}93.3 \pm 23.9 \\
* * * \# \#\end{array}$ & $\begin{array}{l}21.2 \pm 5.1 \\
\# \#\end{array}$ \\
\hline Group K & $21.2 \pm 3.4$ & $20.7 \pm 4.8$ & $18.4 \pm 0.3$ & $22.1 \pm 3.5$ & $13.3 \pm 0.8$ \\
\hline $\begin{array}{l}\text { Cortisol } \\
(\text { nmol/L) } \\
\text { Group X/K }\end{array}$ & $254.1 \pm 75.3$ & $\begin{array}{l}154.5 \pm 19.5 \\
* * * \#\end{array}$ & $\begin{array}{l}159.0 \pm 5.4 \\
* * \# \#\end{array}$ & $\begin{array}{l}158.3 \pm 9.9 \\
* * *\end{array}$ & $\begin{array}{l}233.0 \pm 43.8 \\
\# \#\end{array}$ \\
\hline Group K & $221.2 \pm 65.1$ & $237.5 \pm 88.5$ & $279.2 \pm 5.1$ & $211.9 \pm 62.9$ & $\begin{array}{l}338.4 \pm 4.3 \\
* *\end{array}$ \\
\hline $\begin{array}{l}\text { Adrenaline }(\mathrm{pmol} / \mathrm{L}) \\
\text { Group X/K }\end{array}$ & $104.0 \pm 13.7$ & $\begin{array}{l}92.0 \pm 0.7 \\
\#\end{array}$ & $89.5 \pm 2.0$ & $92.5 \pm 8.2$ & $\begin{array}{l}95.9 \pm 6.1 \\
\# \# \#\end{array}$ \\
\hline Group K & $94.3 \pm 2.1$ & $\begin{array}{l}103.8 \pm 1.5 \\
*\end{array}$ & $93.5 \pm 1.1$ & $94.1 \pm 0.8$ & $\begin{array}{l}121.3 \pm 1.0 \\
* *\end{array}$ \\
\hline $\begin{array}{l}\text { ACTH } \\
(\mathrm{pmol} / \mathrm{L}) \\
\text { Group X/K }\end{array}$ & $1.7 \pm 0.6$ & $\begin{array}{l}0.9 \pm 0.6 \\
* * \# \# \#\end{array}$ & $\begin{array}{l}0.4 \pm 0.2 \\
* * * \# \# \#\end{array}$ & $\begin{array}{l}0.2 \pm 0.04 \\
* * * \# \# \#\end{array}$ & $\begin{array}{l}1.8 \pm 0.4 \\
\# \#\end{array}$ \\
\hline Group K & $1.9 \pm 0.2$ & $\begin{array}{l}2.2 \pm 0.2 \\
*\end{array}$ & $\begin{array}{l}1.67 \pm 0.2 \\
* *\end{array}$ & $2.0 \pm 0.2$ & $\begin{array}{l}2.4 \pm 0.1 \\
* * *\end{array}$ \\
\hline
\end{tabular}


[14]. The investigations on ketamine effects demonstrate that depending on the dose, plasma cortisol and ACTH could either increase or remain unchanged after its independent application $[15,16]$.

In the authors' experiment, blood $\mathrm{ACTH}$ and cortisol were statistically significantly reduced immediately after the application of anesthetics and this depression persisted in the next study periods. In control group of cats, the concentrations of both hormones were higher than the initial ones, which could be explained by the physiological stress due to manipulation of animals [17].

Studies performed so far affirm that the mechanism of hyperglycemia after application of $\alpha_{2}$-agonists was related to inhibition of insulin secretion via the agonistic effects on $\alpha_{2}$-receptors in pancreatic beta cells, but the effects of ketamine on blood insulin concentrations are variable. According to Maroto et al.[18], blood glucose in dogs is regulated by two opposing mechanisms involving $\alpha^{-}$and $\beta$ adrenoceptor mediated effects. In rabbits, low doses of ketamine were found to have no effects on blood glucose, higher doses result in a substantial $\alpha_{2}$ receptor mediated hyperglycemia and surprisingly, even higher doses induce hypoglycemia mediated via opioid and $\beta$-adrenergic receptors, evident only after blockage of $\alpha_{2}$ receptors with the antagonist yohimbine [19].

In the group of cats with xylazine/ketamine anesthesia, a considerable hyperglycemia was observed immediately after anesthetic drug application. Blood glucose increased until the $2 \mathrm{~h}$ on the background of a progressive hyperinsulinemia and decreased plasma ACTH, adrenaline and cortisol.

The established hyperglycemia and hyperinsulinemia in the anesthetized group was most probably due to the interaction of $\alpha_{2}$-agonists and cataleptics and their concurrent effect on pancreatic $\beta$-adrenergic receptors.

The observed changes in blood cortisol and adrenaline in control cats were obviously too insignificant to alter blood glucose levels, which varied within the physiological range at all sampling intervals.

\section{Conclusions}

The anesthetic drug combination of xylazine and ketamine induces a substantial hyperglycemia at the background of hyperinsulinemia, persisting for more than $120 \mathrm{~min}$. The blood concentrations of stress hormones-ACTH, cortisol and adrenaline-decreased immediately after the application of anesthetics. The changes observed in the control group were specific for manipulation-induced physiological stress.

Xylazine-ketamine anesthesia is easy and appropriate for use in veterinary practice, ensuring systemic stress response inhibition for at least two hours, which is enough for performing medium-duration surgery. The use of tested anesthetics should be avoided in cats with abnormal glucose metabolism due to the occurring significant and prolonged hyperglycemia.

\section{References}

[1] Benson, G. J., Wheaton, L. G., Thurmon, J. C., Tranquilli, W. J., Olson, W. A., and Davis, C. A. 1991. "Postoperative Catecholamine Response to Onychectomy in Isoflurane-Anesthetized Cats: Effect of Analgesics." Vet. Surg. 20: 222-5.

[2] Kanda, T., and Hikasa, Y. 2008a "Neurohormonal and Metabolic Effects of Medetomidine Compared with Xylazine in Healthy Cats." Can. J. Vet. Res. 72: 278-86.

[3] Kanda, T., and Hikasa, Y. 2008b. "Effects of Medetomidine and Midazolam Alone or in Combination on the Metabolic and Neurohormonal Responses in Healthy Cats." Can. J. Vet. Res. 72: 332-9.

[4] Ko, J. C., Mandsager, R. E., Lange, D. N., and Fox, S. M. 2000. "Cardiorespiratory Responses and Plasma Cortisol Concentrations in Dogs Treated with Medetomidine Before Undergoing Ovariohysterectomy." J. Am. Vet. Med. Assoc. 217: 509-14.

[5] Hustveit, O., Maurset, A., and Oye, I. 1995. "Interaction of the Chiral Forms of Ketamine with Opioid, Phencyclidine, Sigma and Muscarinic Receptors." Pharmacol. Toxicol. 77: 355-9.

[6] Slowinska-Srzednicka, J. S., Zgliczynski, S., Soszynski, 


\section{Effect of Xylazine-Ketamine Anesthesia on Blood ACTH, Cortisol, Adrenaline, Insulin and Glucose in Ovariohysterectomized Cats}

P., Pucilowska, J., Wierzbicki, M., and Jeske, W. 1988. "Effect of Clonidine on Beta-Endorphin, ACTH and Cortisol Secretion in Essential Hypertension and Obesity.” Eur. J. Clin. Pharmacol. 35: 115-21.

[7] Shceinin, M., and Macdonald, E. 1989. "An Introduction to the Pharmacology of $\alpha_{2}$-Adrenoceptors in the Central Nervous System." Acta Vet. Scand. 85: 11-9.

[8] Maze, M., Virtanen, R., Daunt, D., Banks, S. J., Stover, E. P., and Feldman, D. 1991. "Effects of Dexmedetomidine, a Novel Imidazole Sedative-Anesthetic Agent, on Adrenal Steroidogenesis: In Vivo and in Vitro Studies." Anesth. Analg. 73: 204-8.

[9] Benson, G. J., Grubb, T. L., and Neff-Davis, C. 2000. "Perioperative Stress Response in the Dog: Effect of Pre-emptive Administration of Medetomidine." Vet. Surg. 29: 85-91.

[10] Pfeifer, G., Tauberger, G., Schulte, A., and Esch, J., 1981. "Wirkungen von Ketamine auf den zantralen Sympathikus, die Atmung und den Kreisalauf im Tierexperiment." Anesth. Intensiv. Ther. Notfallmed. 3: $125-74$

[11] Ambrisko, T. D., Hikasa, Y., and Sato, K. 2005. "Influence of Medetomidine on Stress-Related Neurohormonal and Metabolic Effects Caused by Butorphanol, Fentanyl, and Ketamine Administration in Dogs." Am. J. Ve.t Res. 66: 406-12.

[12] Jager, L. P., De Graaf, G. J., and Widjaja-Greefkes, H. C. 1998. "Effects of Atipamezole, Detomidine and Medetomidine on Release of Steroid Hormones by Porcine Adrenocortical Cells in Vitro." Eur. J. Pharmacol. 346: 71-6.

[13] Ambrisko, T. D., and Hikasa, Y. 2002. "Neurohormonal and Metabolic Effects of Medetomidine Compared with Xylazine in Beagle Dogs.” Can. J. Vet. Res. 66: 42-9.

[14] Saha, J. K., Xia, J., Grondin, J. M., Engle, S. K., and Jakubowski, J. A. 2005. “Acute Hyperglycemia Induced by Ketamine/Xylazine Anesthesia in Rats: Mechanisms and Implications for Preclinical Models." Exp. Biol. and Med. 10: 777-84.

[15] Krystal, J. H., Karper, L. P., Seibyl, J. P., Freeman, G. K., Delaney, R., Bremner, J. D., Heninger, G. R., Bowers, M. B., and Charney, D. S. 1994. "Subanesthetic Effects of the Noncompetitive NMDA Antagonist, Ketamine, in Humans. Psychotomimetic, Perceptual, Cognitive, and Neuroendocrine Responses." Arch. Gen. Psych. 51: 199-214.

[16] Hergovich, N., Singer, E., Agneter, E., Eichler, H. G., Graselli, U., Simhandl, C., and Jilma, B. 2001. "Comparison of the Effects of Ketamine and Memantine on Prolactin and Cortisol Release in Men: A Randomized, Double-Blind, Placebo-Controlled Trial." Neuropsychopharm. 24: 590-3.

[17] Rand, J. S., Kinnaird, E., Baglioni, A., Blackshaw, J., and Priest, J. 2002. "Acute Stress Hyperglycemia in Cats Is Associated with Struggling and Increased Concentrations of Lactate and Norepinephrine." J. Vet. Intern. Med. 16: 123-32.

[18] Maroto, R., Calvo, S., Sancho, C., and Esquerro, E. 1992. "Alpha- and Beta- Adrenoceptor Cross-Talk in the Regulation of Glycogenolysis in Dog and Guinea-Pig Liver." Arch. Int. Pharmacodyn. Ther. 317: 35-46.

[19] Sharif, S. I. 2009. "Effect of Intravenous Ketamine Administration on Blood Glucose Levels in Conscious Rabbits." Am. J. Pharm. \& Toxicol. 4: 38-45. 